\title{
GRAVE HUMAN RIGHTS VIOLATIONS AND CRIMES AGAINST HUMANITY UNDER PUBLIC INTERNATIONAL LAW: THE CASE OF MEXICO
}

\author{
Violaciones graves a derechos humanos y crímenes contra la humanidad \\ en el Derecho Internacional Público: el caso de México
}

Dorothy ESTRADA TANCK*

\begin{abstract}
Summary:
I. Introduction II. International law on grave human rights violations and crimes against humanity III. The case of Mexico in light of applicable international law IV. Normative framework on grave human rights violations and Crimes Against Humanity V. Some reflections on legal application and interpretation issues VI. Conclusions.
\end{abstract}

\begin{abstract}
The UN international legal framework on grave human rights violations and crimes against humanity has developed in recent years, to the degree of an initiative for an autonomous treaty on crimes against humanity. Mexico has undergone several Constitutional and legal reforms accepting the priority and legal supremacy of international human rights instruments but confronting one of the worst humanitarian crises of its history. This article reviews the relationship between international law in this area and the specific factual, legal and methodological problems and efforts undergone by different actors in Mexico and proposes ways to step closer to fulfilling victims' internationally recognized rights to truth, justice and reparations.
\end{abstract}

Keywords: Grave human rights violations, Crimes against humanity, Enforced disappearance, Public international law, Mexico

Resumen: El marco jurídico internacional de las Naciones Unidas sobre violaciones graves de los derechos humanos y crimenes de lesa humanidad se ha desarrollado en los últimos años al grado de una iniciativa para un tratado autónomo sobre crímenes

* Doctora en Derecho por el Instituto Universitario Europeo de Florencia. Profesora de Derecho Internacional Público y Relaciones Internacionales de la Universidad de Murcia, España. Colaboradora invitada del proyecto Derechos Humanos y Justicia Internacional de la Facultad de Derecho de la Universidad Autónoma de Tlaxcala, México. 
de lesa humanidad. México ha sufrido varias reformas constitucionales y legales que aceptan la prioridad y la supremacía de los instrumentos internacionales de derechos humanos, pero al mismo tiempo enfrenta una de las peores crisis humanitarias de su historia. Se revisa la relación entre el derecho internacional en esta área y los problemas y esfuerzos fácticos, jurídicos y metodológicos especificos realizados por diferentes actores en México y se proponen formas de acercarse a mecanismos más adecuados para realizar los derechos internacionalmente reconocidos de las víctimas a la verdad, la justicia y las reparaciones.

Palabras clave: Violaciones graves a derechos humanos, Crímenes de lesa humanidad, Desaparición forzada, Derecho internacional público, México

\section{Introduction}

In the last years, the international legal framework at the level of the United Nations (UN) on grave human rights violations and crimes against humanity $(\mathrm{CAH})$ has developed significantly. The most transcendental aspect is probably the proposal for an autonomous treaty on crimes against humanity, and the draft articles on these crimes currently being discussed by the UN International Law Commission, which could prove a positive step closer to victims' right to truth, justice and reparations.

In parallel, Mexico has undergone several legal changes, including Constitutional reforms, which recognize the priority and legal supremacy of international human rights instruments and which devise or reformulate the institutional mechanisms crafted to protect them. Against the mostly progressive human rights normative background that will be reviewed below, the factual reality of grave human rights violations couldn't be more appalling. This has led to what some have termed as the human rights paradox, whereby Mexico now enjoys a solid legal and institutional architecture in human rights, but at the same time it is living one of the worst humanitarian crisis of the last forty years. This crisis is not easily classifiable in international legal terms given that Mexico is neither a country engaged in an open armed conflict nor a country undergoing a recent transition from an authoritarian regime to a democratic rule of law ${ }^{1}$.

Indeed, for a country not involved in a formal armed conflict, statistics regarding homicides, enforced disappearances, and the use of torture in Mexico are overwhelming. The country's war on drugs has resulted in the most violent period in the country's modern history, with more than 150,000 people killed since $2006^{2}$, more than 33,000 disappeared and thou-

\footnotetext{
1 See in this sense Dondé Matute, Javier (2018), "Una propuesta de justicia transicional para México", in Animal Político, 26 September.

2 Open Society Justice Initiative, Atrocidades Innegables: Confrontando Crímenes de Lesa Humanidad en México, 2016. Other figures indicate that roughly 200,000 people have been murdered during 2006 to 2016, see FiDH (International Federation on Human Rights, 2017), "Mexico: Murders, Disappearances, and Torture in Coahuila de Zaragoza are Crimes against Humanity", 5 July 2017, [on line], available at https://www.fidh.org/en/region/americas/mexico/mexico-murders-disappearances-and-torture-in-coahuila-de-zaragoza-are
} 
sands tortured ${ }^{3}$. At times these numbers have been challenged, but while the precise quantities are disputed, there is certitude in the fact that the figures of extremely grave crimes are very large. This dimension brings up the question of considering the entry of such cases into the realm of crimes against humanity ${ }^{4}$. On the other hand, the fact that the violence stems from the war on drugs with the intervention of organized criminal groups (and not only the State) has raised doubts as to the adequacy of studying the cases through the lens of $\mathrm{CAH}$, a reticence which has been challenged ${ }^{5}$, and which may slowly become residual if one considers the admission in February 2018 by the ICC to start a preliminary investigation of the Philippines for the first time for alleged crimes deriving from its war on drugs 6 .

The emblematic case of the 43 students of the teachers' school in Ayotzinapa, Guerrero -one of the poorest states in the country-, victims of enforced disappearance on 26 September 2014 (and only one of them confirmed as killed, Alexander Mora)-, by organized crime with intervention of the local mayor of the town of Iguala and the local police ${ }^{7}$, and seemingly also with the involvement of federal police and/or the $\mathrm{Army}^{8}$, has awakened national and international attention to the seriousness of the problem. - Other cases such as the death of 22 civilians by soldiers in 2014, of which 12 were reportedly executed extrajudicially; or the extrajudicial execution of 22 to 42 civilians by federal police during a confrontation in 2015 in Tanhuato, in the south-east state of Michoacán, have stirred the country's conscience to its core. However, at the date of writing this article in 2018, impunity regarding these cases remains rampant with almost no convictions for these crime ${ }^{9}$, and the Mexican Government has not implemented the recommendations that the Interdisciplinary Group of Independent Experts (GIEI, by its Spanish acronym) of the Inter-American Commission of Human Rights, created to the effect of investigating the case of Ayotzinapa, has formulated in its two reports. More than four years have passed and the students' whereabouts remain unknown, and no new arrests have been made of State actors who might have participated on the night the events in Iguala ${ }^{10}$. On the other hand, in June 2018, a federal court reopened the Ayotzinapa case and instructed that an Investigative Commission for Justice and

3 Human Rights Watch (2018), World Report 2018-Mexico, [on line], available at https://www.hrw.org/es/ world-report/2018/country-chapters/313310.

4 Pérez-León Acevedo, Juan Pablo (2017), "The Close Relationship Between Serious Human Rights Violations and Crimes Against Humanity: International Criminalization of Serious Abuses", in Anuario Mexicano de Derecho Internacional, 147, vol. XVII, pp. 145-186.

5 Robinson, Darryl (2015), "Mexico: The War on Drugs and the Boundaries of Crimes Against Humanity", in EJIL: Talk!, 26 May, [on line], available at https://www.ejiltalk.org/mexico-the-war-on-drugs-and-theboundaries-of-crimes-against-humanity/.

6 See ICC data, [on line], available at https://www.icc-cpi.int/philippines.

7 See, eg, Open Society Justice Initiative, Atrocidades Innegables: Confrontando Crímenes de Lesa Humanidad en México, 2016. The unresolved 2014 kidnapping and apparent killing of 43 students from the Ayotzinapa teacher-training college has been one of the most high-profile cases receiving international attention. The report was based on documents and interviews over a nine-year period from 2006 to 2015. It cited mass graves and thousands of disappearances, in addition to killings such as the shooting by the army of 22 suspected gang members in Tlatlaya in central Mexico, and similar incidents, as evidence of criminality in the government's war against the country's drug cartels.

8 Inter-American Commission on Human Rights (2018), Situation Report. Special Follow-up Mechanism to the Ayotzinapa Case of the IACHR, OEA/Ser.L/V/II, Doc. 82, 5 June, paras. 49; 66-70; and 71-76.

9 Human Rights Watch, op. cit. note 3.

${ }^{10}$ Inter-American Commission on Human Rights, Situation Report. Special Follow-up Mechanism to the Ayotzinapa Case of the IACHR, op. cit. p. 106. 
Truth be created to clarify what really happened to the 43 students, adopting a measure that is often used in transitional justice mechanisms ${ }^{11}$.

Multiple legal and normative measures, including the adoption of a General Law on Victims in 2013, early alert mechanisms, public policy initiatives, commissions, agencies, institutional reforms, and coordination strategies have been adopted between 2010 and the date of writing this article in $2018^{12}$, but in light of the staggering reality and the growing numbers and seriousness of the violations involved, they are clearly insufficient and the institutional structure is evidently overcome ${ }^{13}$.

Serious methodological, technological and transparency problems remain in relation to counting the victims, constructing trustworthy databases, coordinating and systematizing the information on victims, patterns of abuse and actors involved within a federal system formed by the federal authorities and 32 federative entities ( 31 states and Mexico City), and adequately mapping, identifying and diagnosing the extremely complex and multilayered phenomenon of new forms of violence and human rights violations in Mexico ${ }^{14}$. There is a constant reticence by government authorities to openly admit the seriousness of the problems and frequently the public is denied basic information ${ }^{15}$.

A communication presented to the International Criminal Court (ICC) by civil society organisations documenting alleged crimes against humanity perpetrated in the state of

\footnotetext{
${ }^{11}$ See Dondé Matute, op. cit. note 1.

${ }^{12}$ See, e.g. Procuraduría General de la República (2013), Acuerdo A/066/13 por el que se crea la Unidad Especializada de Búsqueda de Personas Desaparecidas y se establecen sus facultades, Diario Oficial de la Federación, 21 June 2013; GARDUÑO, SiLVIA (2014), "Alistan herramienta para desaparecidos", Reforma Newspaper, 12 October; FUNDAR (CENTRo De AnÁlisis e Investigación, 2014), Movimiento por la Paz con Justicia y Dignidad (MPJD), SERAPAZ, Presentación de información en el marco de la adopción de la lista cuestiones en la Séptima Sesión del Comité Contra las Desapariciones Forzadas 15-26 de septiembre de 2014. Primera revisión a México por el Comité contra las Desapariciones Forzadas de la Organización de las Naciones Unidas, 1 June 2014; Report presented by the Mexican State to the UN Committee on Enforced Disappearances, paras. 228-231.

${ }^{13}$ Human Rights Watch (2014), Mexico: "Disappearances” Response Falls Short: Inexplicable Delays, Contradictory Statements, Limited Results, 8 October, [on line], available at http://www.hrw.org/ news/2014/10/08/mexico-disappearances-response-falls-short.

${ }^{14}$ See, e.g. Aristegui Noticias (2014), "La PGR no quiere transparentar su investigación sobre la matanza de Tlatlaya", 11 December 2014, [on line], available at http://aristeguinoticias.com/0812/mexico/ la-pgr-no-quiere-transparentar-su-investigacion-sobre-la-matanza-de-tlatlaya/.; FUNDAR, op. cit. note 12; Acuerdo de PGR, [on line] available at http://dof.gob.mx/nota_detalle.php? codigo $=5368881 \& f e-$ cha $=20 / 11 / 2014$; Human Rights Watch (2013), "Mexico: Build Accurate Database of Disappeared", 12 November, [on line], available at http://www.hrw.org/news/2013/11/12/mexico-build-accurate-database-disappeared.

${ }^{15}$ For instance, the NGO Comisión Mexicana para la Defensa y Promoción de los Derechos Humanos (CMDPDH) has requested the disclosure of several reports part of the criminal investigation of the massacre of Tlatlaya, but PGR has rejected to comply with this request it arguing this is part of an ongoing investigation, usually a valid basis for rejection, except in the cases of grave human rights violations, as set forth by Mexican law and by the jurisprudence of the Inter-American Court of Human Rights; see Aristegui Noticias, op. cit. note 14. Consider also the lack of public access of the agreement entered into between PGR and the International Committee of the Red Cross for them to provide the software of its database Ante Morten Post Mortem (AMPM) to be implemented by the Mexican authorities as part of the implementation of the UN Convention on Enforced Disappearance, which was not published in the official journal (Diario Oficial de la Federación, DOF) and has been requested access by NGOs without success (FUNDAR, MJPD, SERAPAZ, op. cit. note 12, p. 17).
} 
Baja California, was rejected in 2015, after which two other ones have been submitted to the ICC's Office of the Prosecutor requesting it to open preliminary examinations in relation to alleged crimes against humanity committed in Mexico: one regarding the murders, disappearances and torture of migrants in the Mexican northern state of Coahuila, presented in 2017; and another one submitted on 11 June 2018 concerning alleged crimes against humanity, such as murders, torture, sexual violence, and enforced disappearances, committed by the Mexican Army against the civilian population in Chihuahua between 2008 and $2010^{16}$. These requests are pending decision by the ICC's Office of the Prosecutor.

Promising aspects like the adoption and entry into force of a General Law on Torture in June 2017 and of a General Law on Enforced Disappearances in January 2018 open the way for working against impunity and in favor of truth, justice and reparations for victims. Such laws, due to their general legal character, are applicable both to federal authorities and to local authorities at the state and municipal levels in the country's 32 federative entities (31 states and Mexico City). These laws contrast, however, with other incidents such as the adoption of the Law on Interior Security, approved in 2017. This law has been received with preoccupation and dismay by international and national human rights bodies, academics and activists alike, given that it legalizes the intervention of the Army in police functions originally designed for civilian forces ${ }^{17}$, although one can mention as a sign of hope that the constitutionality of this measure has been challenged by federal judges ${ }^{18}$.

In light of this fact, an analysis of the international law on grave violations and crimes against humanity becomes necessary, so as to reflect its linkage and possible applicability to the concrete case of Mexico. A review of the national legislation on these issues is crucial as well, in order to map the current legislative and judicial avenues available and to assess whether such openings are sufficient to meet the rights of victims as contemplated by international law.

\section{International law on grave human rights violations and crimes against humanity}

Research carried out regarding the consideration of grave human rights violations, signals that international human rights instruments and international legal practice do not use a uniform terminology. Gross, flagrant, grave, serious, and other qualifiers (egregious, massive) are frequently used interchangeably and sometimes cumulatively ${ }^{19}$.

\footnotetext{
${ }^{16}$ See FidH (International Federation on Human Rights, 2017), "Mexico: Murders, Disappearances, and Torture in Coahuila de Zaragoza are Crimes against Humanity", 5 July, [on line], available at $h t$ tps://www.fidh.org/en/region/americas/mexico/mexico-murders-disappearances-and-torture-in-coahuila-de-zaragoza-are; and FIDH (2018), "Military and civil authorities reported to the International Criminal Court for crimes against humanity committed in Chihuahua, Mexico", 11 June, [on line], available at https://www.fidh.org/en/region/americas/mexico/military-and-civil-authorities-reported-to-the-international-criminal.

${ }^{17}$ See, e.g. General Gallardo (2018), "Ley de Seguridad Interior y la Corte Penal Internacional”, Sin Embargo, 17 January, [on line], available at $h t t p: / / w w w . s i n e m b a r g o . m x / 17-01-2018 / 3374562$.

${ }^{18}$ LASTRI, Diana (2018), "Dos jueces consideran inconstitucional la Ley de Seguridad Interior", El Universal, 11 May, [on line], available at http://www.eluniversal.com.mx/nacion/dos-jueces-consideran-inconstitucional-la-ley-de-seguridad-interior\#.WvZGDRPdZ38.twitter.

${ }^{19}$ Geneva Academy of International Humanitarian Law and Human Rights (2014), What amounts to 'a serious violation of international human rights law'? An analysis of practice and expert opinion for the
} 
The UN International Law Commission's Draft Articles on Responsibility of States for Internationally Wrongful Acts, include a test of seriousness in Article 40, which states that a breach of a peremptory norm of general international law (that is, a ius cogens norm) is serious if it involves a gross or systematic failure by the responsible State to fulfil the relevant obligation ${ }^{20}$. Similarly, Article 7 of the UN Arms Trade Treaty adopted in 2013 sets forth that a proposed export that is likely to result in a 'serious' violation of human rights should not be allowed to proceed.

At the same time, the framework on grave violations of human rights encompasses intersecting issues of international human rights law, international humanitarian law, international criminal law, and international refugee law, that is, put more broadly humanity's law or the common law of humanity ${ }^{21}$. Often the scope of 'serious violations' coincides or virtually coincides with violations that involve individual criminal responsibility under international law, notably crimes against humanity and war crimes, as those contemplated by the Rome Statute of the International Criminal Court and by customary law as well ${ }^{22}$. Indeed, even since 1968, the UN Convention on the Non-Applicability of Statutory Limitations to War Crimes and Crimes against Humanity had concluded that the gravity of these crimes called for the non-applicability of statutory limitations for their investigation and prosecution. The intersection of these different legal regimes in turn makes it difficult to identify which is exactly applicable, and in a given context more than one (or all) may be relevant to a certain situation, rendering important the reflection on this type of violations and the avenues to make each normative body operational. What does seem to be the common denominator is that when human rights violations become undoubtedly grave, other bodies of law take effect. As such, they must not be minimized or left aside,

purpose of the 2013 Arms Trade Treaty, Geneva Academy, August, p. 34. See also Medina Quiroga, Cecilia (1988), The Battle of Human Rights, Gross, Systematic Violations and the Inter-American System, Martinus Nijhoff, Dordrecht, The Netherlands, p. 16; and UN (2011), "Human Rights Due Diligence Policy on UN support to non-UN security forces (HRDDP)", p. 3, para. 12, on the definition of Grave violations comprising elements of international human rights, refugee, criminal and humanitarian law.

${ }^{20}$ See also Report of the UN Secretary-General to the Security Council on the protection of civilians in armed conflict, UN doc. S/2004/431, 28 May 2004, para. 3.

${ }^{21}$ On these concepts and terminology, see CASSESE, Antonio (2005), International Law, Oxford, Oxford University Press, second edition, p. 45; CANÇAdo Trindade, Antonio Augusto (2006), A humanizaçao do direito internacional, Editora del Rey, Brasil, at pp. 322-324, and by the same author International Law for Humankind: Towards a New Jus Gentium, Martinus Nijhoff Publishers, The Netherlands, July 2010; Sunga, Lyal S., "The Concept of Human Security: Does it Add Anything of Value to International Legal Theory or Practice?" in Frick, Marie-Luisa and Oberprantacher, Andreas (editors), Power and Justice in International Relations. Interdisciplinary Approaches to Global Challenges, Ashgate Publishers, December 2009, pp. 131-148; and Teitel, Ruti G., Humanity's Law, Oxford University Press, 2011, pp. 35-69; 105-138.

${ }^{22}$ See, e.g. Report of the International Commission of Inquiry on Darfur to the United Nations Secretary-General, Pursuant to Security Council Resolution 1564 of 18 September 2004, para. 175; Report of the Commission of Inquiry on Lebanon pursuant to Human Rights Council resolution S-2/1, UN doc. A/HRC/3/2, 23 November 2006, para. 68; Report of the International Commission of Inquiry on Côte d'Ivoire, UN doc. A/HRC/17/48, 1 July 2011, paras. 39-65 and 66; Report of the independent international commission of inquiry on the Syrian Arab Republic, UN doc. A/HRC/22/59, 5 February 2013, Summary; Report of the independent international commission of inquiry on the Syrian Arab Republic, UN doc. A/HRC/24/46, 16 August 2013, Summary; Report on Violations and Abuses of International Human Rights Law and Violations of International Humanitarian Law in the Context of the Fighting in Juba, South Sudan, in July 2016, UN Mission in South Sudan, January 2017, para. 16. 
but rather they should necessarily find their place in a thorough scholarly analysis and a practical map road for action.

Elements that have been taken into consideration in international human rights law on grave violations include the character of the right, the magnitude of the violation, the type of victim (assessing conditions of vulnerability), and the impact of the violation ${ }^{23}$. International instruments on violations generally deemed as serious or grave have been adopted in the realm of torture, enforced disappearance or racial discrimination, in the form of the 1965 International Convention on the Elimination of All Forms of Racial Discrimination (ICERD), the 1984 UN Convention against Torture and Other Cruel, Inhuman or Degrading Treatment or Punishment (UNCAT), and more recently the 2006 International Convention for the Protection of All Persons from Enforced Disappearance (ICPPED). However, one must also consider that the spectrum of rights where a serious violation has been found may include violations of economic, social and cultural as well as civil and political rights, and individual as well as collective violations ${ }^{24}$. In addition, the quantity criterion helps to establish the existence of a serious human rights violation ${ }^{25}$. Indeed, quantity may relate to the magnitude and impact of the violation, and it is also linked to the systematic character often coupled by human rights instruments to grave violations.

In the scope of international human rights instruments, references related to the notion of serious violation can be found in the Optional Protocol to the 1979 Convention on the Elimination of All Forms of Discrimination against Women (OP-CEDAW), and the Optional Protocol to the 1966 International Covenant on Economic, Social and Cultural Rights (OP-ICESCR). Article 8 of OP-CEDAW allows the UN Committee on the Elimination of Discrimination against Women to initiate a confidential investigation by one or more of its members where it has received reliable information of grave or systematic violations by a state party of rights established in the Convention. Actually, an investigation of this type was initiated in 2004 against Mexico for the feminicides occurred in Ciudad Juárez, Chihuahua, as will be reviewed in the following section. Article 11 of OP-ICESCR reproduces almost literally the language of OP-CEDAW. Similarly, the UN Committee on Economic, Social and Cultural Rights holds the faculty to examine situations of grave or systematic violations of any of the economic, social, and cultural rights set out in the Covenant.

As is well known, in the realm of international criminal law, the most developed normative standard in this area, the Rome Statute of the International Criminal Court, contemplates in Article 7,1) as crimes against humanity several acts that meet the threshold of serious violations, such as enforced disappearance, torture, apartheid, extrajudicial killings, rape, enforced sterilization, or forced pregnancy, when they meet the chapeau requirement of being committed as part of a widespread or systematic attack directed against any civilian population, with knowledge of the attack. Article7,2, a. clarifies that

\footnotetext{
${ }^{23}$ Geneva Academy, op. cit. note 19, p. 34.

${ }^{24}$ Ídem. See also pp. 6, 31 and 32; and UN (2010), Committee on Economic, Social and Cultural Rights (CESCR), Report of Israel, (Third Periodic Report/List of Issues and Written Replies), UN doc. E/C.12/ ISR/Q/3/Add.1, pp. 4-5, para. 36; CESCR, Concluding Observations: Sri Lanka, UN doc. E/C.12/LKA/ CO/2-4, 9 December 2010, para. 28; CESCR, Concluding Observations: Jamaica, UN doc. E/C.12/1/ Add.75, 6 December 2001, para. 14.

${ }^{25}$ Geneva Academy, op. cit. note 19, pp. 15-16.
} 
an attack directed against any civilian population means a course of conduct involving the multiple commission of acts referred to in paragraph 1 against any civilian population, pursuant to or in furtherance of a State or organizational policy to commit such attack.

In recent years, a draft treaty on crimes against humanity has been proposed and discussed by the Crimes Against Humanity Initiative, an academic research and advocacy project that promotes the need for a comprehensive international convention on the prevention and punishment of crimes against humanity, the analysis of the necessary elements of such a convention, and the drafting of a proposed treaty. To date, the Initiative has carried out several meetings of experts and conferences, it has published a Proposed Convention on the Prevention and Punishment of Crimes Against Humanity, and its work has resulted in the publication of an edited volume, Forging a Convention for Crimes Against Humanity. The draft treaty is currently being debated by the UN International Law Commission and by several governments. The UN International Law Commission's 2017 Draft Articles on Crimes Against Humanity were submitted to the General Assembly in fall 2017, and they mark a crucial step towards achieving a new global convention on preventing and punishing crimes against humanity. The ILC is accepting comments from governments, international organizations, civil society, and others until December 1, 2018. The ILC will complete a second reading of the Draft Articles in 2019, after which a new treaty may be adopted by the UN General Assembly or a diplomatic conference in 2019 or $2020^{26}$.

In the context of this normative framework, regarding the grave and high-quantity violations that have occurred and continue to take place in Mexico, all the reviewed criteria are met, and thus the study of this reality must consider existing international standards.

\section{The case of Mexico in light of applicable international law}

\section{Factual background and institutional mechanisms}

To systematize the analysis on the specific case of Mexico, some of the central the issues implicated in the humanitarian crisis it is going through have been grouped according to the type of human rights violation and/or the sector of the population most gravely affected:

Abuse by the army: The National Human Rights Commission (CNDH, by its acronym in Spanish) asserted that from the end of 2006 to September 2013, it received 8,150 complaints of abuse by the army. Among this huge number of complaints, it has found at least 116 cases in which army personnel is responsible of the perpetration of serious human rights violations ${ }^{27}$. The problem of army intervention in civil police functions with insufficient control and accountability become especially evident with the case of the massacre of 22 persons with military intervention in Tlatlaya, State of Mexico, on 30 June 2014. Certain sources have also indicated possible intervention of the Army in the

\footnotetext{
${ }^{26}$ See Crimes Against Humanity Initiative, [on line], at http://law.wustl.edu/WashULaw/crimesagainsthumanity/.

${ }^{27}$ Human Rights Watch (2014), World Report 2014-Mexico, [on line], available at http://www.hrw.org/ world-report/2014/country-chapters/mexico.
} 
disappearance of the 43 student teachers of Ayotzinapa ${ }^{28}$, a fact that is especially troubling considering the newly elected President, Andrés Manuel López Obrador, has announced his intention of keeping the Army in policing and security functions -albeit with a more humane face- once he takes office in December 2018.

Threats and violations against human rights defenders and journalists: Analysing the official records provided by the $\mathrm{CNDH}$, the numbers are worrying. The CNDH indicated cases of abuses against human rights defenders such as attacks against personal integrity and security, personal liberty and property possession. The investigations have identified as allegedly responsible for these acts some authorities of the Attorney General's Office, the Department of National Defense (the Army), the Ministry of the Interior, the Federal Police and the Attorney General of the state of Chihuahua ${ }^{29}$. The Office in Mexico of the United Nations High Commissioner for Human Rights has registered dozens of aggressions against human rights defenders and none has resulted in a conviction ${ }^{30}$. The CNDH has also recorded a high number of attacks against media workers. The main abuses registered against journalists were violations of their legal security, freedom, integrity, dignity and personal safety. Again, the CNDH identified Mexican authorities as possible perpetrators, among them, the Attorney General of the State of Veracruz ${ }^{31}$.

Migrants: migrants, particularly undocumented migrants in transit through Mexico, are extremely vulnerable to human rights violations. Suffice it to describe the San Fernando massacre ${ }^{32}$, where marines discovered in 2010 a mass grave with 72 bodies of persons from Ecuador and Brazil, among other nationalities. The CNDH denoted that the immigrants are often subjected to abduction, human trafficking, sex violence and child pornography in hands of organized crime ${ }^{33}$. Many children are also recruited by the organized crime to fight criminal rivalries, drug trafficking and drug war. The scale and gravity of this phenomenon, and more particularly of the murders taking place against migrants, has recently prompted the analysis that such murders certain circumstances as a result of a concrete migratory law and policy, may be considered a crime

${ }^{28}$ See, e.g. Gómez Romero, Luis (2018), "Massacres, disappearances and 1968: Mexicans remember the victims of a perfect dictatorship", The Conversation, 5 October, [on line], available at https://theconversation.com/massacres-disappearances-and-1968-mexicans-remember-the-victims-of-a-perfect-dictatorship-104196.

${ }^{29}$ Comisión Nacional de los Derechos Humanos (2013), Agenda Nacional de Derechos Humanos 2013, México, p. 31, [on line], available at http://www.cndh.org.mx/sites/all/fuentes/documentos/conocenos/ Agenda_2013_1.pdf.

${ }^{30}$ Human Rights Watch, op. cit, note 27.

${ }^{31}$ Comisión Nacional de los Derechos Humanos, op. cit. note 29, p. 33.

${ }^{32} \mathrm{See}$ 'La CNDH señala violación de derechos por parte de la PGR y gobierno de Tamaulipas en matanza de San Fernando', Sin embargo, 27 December 2013; see also Comisión Nacional de los Derechos Humanos, Recomendación No. 80/2013 Caso de Privación de la vida de 72 personas migrantes y atentados a la vida de los extranjeros, en el Municipio de San Fernando, Tamaulipas, Mexico, 2013, [on line], available at http://www.cndh.org.mx/sites/all/fuentes/documentos/Recomendaciones/2013/REC_2013_080.pdf; Comité de Migrantes Fallecidos y Desaparecidos de El Salvador et al. Informe, Situación de las personas migrantes no localizadas y restos no identificados en México, p. 9, [on line], available at http://www. fundacionjusticia.org/wp-content/uploads/2013/06/ANEXO-17-INFORME-CIDH-Migrantes-no-localizados-y-restos-no-identificados-en-Mexico.pdf; see also CNN México (2010), "La marina encuentra una fosa con 72 cuerpos en un rancho en Tamaulipas", 25 August.

${ }^{33}$ Comisión Nacional de los Derechos Humanos, op. cit. note 29, p. 34. 
against humanity and, as such, susceptible of being investigated by the International Criminal Court ${ }^{34}$.

Extrajudicial killings: Currently, Mexico is also living a horrendous moment of its history regarding this type of killings. More than 150,000 people have been killed since $2006^{35}$. The CNDH had showed that from 2005 to 2012 there were 48,750 violent homicides registered and only in 2011 a total of 10,696. In the annual report of 2013 of Amnesty International the number is bigger since it affirms that almost 60,000 people have $\operatorname{died}^{36}$. According to other NGOs there were at least 67 extra judicial killings perpetrated during the presidency of Calderón, based on political motives ${ }^{37}$. The CNDH identified as allegedly responsible for these acts, state officials, criminals acting with the consensus of the public authorities and members of organized crime ${ }^{38}$. Regarding human trafficking, records registered by the $\mathrm{CNDH}$ are shocking because it reported that between 16,000 and 20,000 children are sex slaves ${ }^{39}$.

Violence against women and feminicide: Although feminicide is spread in all the country, the main cases registered are in Ciudad Juárez, Chihuahua, and in the state of Mexico (Estado de México). On the topic, the CNDH's has identified the complicity of several members of the different levels of government ${ }^{40}$ and -again- it is not possible to conclude an official number of people involved. Women often experience a double victimization: firstly, as victims of grave human rights violations; and secondly, when trying to access the formal justice system, which frequently leaves them alone, discriminated against, and unprotected, as evidenced in the case of mothers, sisters or wives of disappeared people when searching for their loved ones, in many cases themselves women and girls -as evidenced in the paradigmatic and sadly well-known case of Cotton Field v. Mexico before the IACHR.

Disappearances and enforced disappearances: officially recognized figures at 2018 indicate that there are around 33,000 persons missing or disappeared ${ }^{41}$. The CNDH had

${ }^{34}$ See, e.g. Castilla Juárez, Karlos (2018), “Asesinato de personas migrantes sine permissum en tránsito ¿un crimen de lesa humanidad competencia de la Corte Penal Internacional?", in Revista Mexicana de Ciencias Penales, No. 4, abril-junio, pp. 21-47.

${ }^{35}$ Open Society (2016), Justice Initiative, Atrocidades Innegables: Confrontando Crímenes de Lesa Humanidad en México. Other figures indicate that roughly 200,000 people have been murdered during 2006 to 2016, see FidH (International Federation on Human Rights, 2017), "Mexico: Murders, Disappearances, and Torture in Coahuila de Zaragoza are Crimes against Humanity", 5 July, [on line], available at $h t$ tps://www.fidh.org/en/region/americas/mexico/mexico-murders-disappearances-and-torture-in-coahuila-de-zaragoza-are.

${ }^{36}$ Amnesty International (2013), "Informe Anual 2013-Mexico", [on line], available at $h t t p: / / w w w . a m n e s-$ ty.org/es/region/mexico/report-2013.

${ }^{37}$ Comité Cerezo México et al, Defender los derechos humanos en México: el costo de la dignidad Junio de 2012 a mayo de 2013, p. 71, [on line], available at http://www.pbi-mexico.org/fileadmin/user_files/ projects/mexico/files/Reports/1308DefenderDDHHMexico_CerezoAcuddeh.pdf

${ }^{38}$ Comisión Nacional de los Derechos Humanos, op. cit. note 29, pp. 43-44.

${ }^{39} \mathrm{Idem}$.

${ }^{40} \mathrm{Idem}$.

${ }^{41}$ Registro Nacional de Datos de Personas Extraviadas o Desaparecidas, Secretariado Ejecutivo del Sistema Nacional de Seguridad Pública, [on line], available at https:/www.gob.mx/sesnsp/acciones-y-programas/ registro-nacional-de-datos-de-personas-extraviadas-o-desaparecidas-rnped. 
reported that until 31 December 2012, approximately 42,300 persons were missing ${ }^{42}$. Some NGOs speak about a larger number of disappearances since they calculate an approximate of 30,000 missing people only from 2006 to $2012^{43}$.

The numbers are in accordance with other situations of perpetration of mass atrocities. For example, after seven years of the ruling of the Military Juntas, Argentina faced between 20,000 and 30,000 disappearances ${ }^{44}$. The situation became worse after those years, given that several cases of enforced disappearances were carried out by public authorities, military personnel-related ${ }^{45}$ or by individuals acting with direct or indirect support of public officials ${ }^{46}$ or with their acquiescence. On 20 May 2014 Raúl Plascencia Villanueva, former President of the $\mathrm{CNDH}$, reported to the Senate that in the cases of disappeared people, considering the period from 2005 to 2014, in 612 cases Mexican authorities are directly involved; in 267 cases organized crime members are involved, while in 24,800 cases it is not possible to rule out the involvement of organized crime and police authorities ${ }^{47}$. The report by Amnesty International picks up information from different NGOs of nearly 24,000 disappeared people ${ }^{48}$. Similarly, the report by Human Rights Watch, Mexico's Disappeared: The Enduring Cost of a Crisis Ignored, of 2013, found that Mexican security forces had participated in widespread enforced disappearances in the context of former president Felipe Calderón's war on drugs, from December 2006 to December $2012^{49}$.

Human Rights Watch called on Mexican authorities to put in place a series of measures to address the issue, including establishing a comprehensive, accurate national database of the disappeared, with information on their physical characteristics and genetic data from relatives, accompanied by a database of unidentified human remains. This would allow officials across the country to access data on the disappeared, facilitating searches and investigation, and would indicate the scale of the problem, helping the authorities to identify patterns and develop preventive measures.

Putting together the figures released by SEGOB in relation to the period of Calderón plus those acknowledged regarding the current period of Peña Nieto, the figure would add up to a total of 20,810 disappeared/missing people (officially recognized) between 2006

42 Comisión Nacional de los Derechos Humanos op. cit. note 29, p. 42.

${ }^{43}$ Comité Cerezo México et al. op. cit. note 37.

${ }^{44}$ Goransky, Mirna and Luis Piqué, María (2010), “(The Lack of) Criteria for the Selection of Crimes Against Humanity Cases: The Case Of Argentina", in Morten Bergsmo, Criteria for Prioritizing and Selecting Core International Crimes Cases, $2^{\text {nd }}$ ed, Oslo, Torkel Opsahl Academic EPublisher, p. 92.

${ }^{45}$ Amnistía Internacional (2009), "México, Nuevos Informes de Violaciones De Derechos Humanos a Manos del Ejército", Londres, pp. 10-14.

${ }^{46}$ Human Rights Council (2011), Report of the Working Group on Enforced or Involuntary, Disappearances Addendum, Mission to Mexico, 20 December, A/HRC/19/58/Add.2, 2011, p. 6

${ }^{47}$ México reporta 24 mil 800 desaparecidos de 2005 a 2014: CNDH; en 612 casos hay ligas directas con autoridades, Sin embargo, [on line], available at http://www.sinembargo.mx/20-05-2014/998784, 20 May 2014; see also La Jornada "De 2005 a la fecha hay 24 mil 800 personas desaparecidas: CNDH", 21 May.

${ }^{48}$ See, [on line], available at http://www.amnesty.ca/research/reports/confronting-a-nightmare-disappearances-in-mexico; HRW, "Mexico's Disappeared: The Enduring Cost of a Crisis Ignored," February 2013, [on line], available at http://www.hrw.org/reports/2013/02/20/mexicos-disappeared.

${ }^{49}$ HRW, "Mexico's Disappeared: The Enduring Cost of a Crisis Ignored," February 2013, [on line], available at http://www.hrw.org/reports/2013/02/20/mexicos-disappeared. 
and May $2014^{50}$. All the above give testimony to the different and even contradictory records according to diverse sources and even among public institutions.

The painfully ground-breaking case of the 43 students of the teachers' school in Ayotzinapa, Guerrero, victims of enforced disappearance by organized crime with intervention of the local mayor of the town of Iguala and the local police, and allegedly of the Army and federal police, on 26 September $2014^{51}$, has stirred up civil society towards understanding the real depth and gravity of the problem.

As was mentioned above, however, at the date of writing this article in 2018, the Mexican Government has not implemented the recommendations that the Interdisciplinary Group of Independent Experts (GIEI, by its Spanish acronym) of the Inter-American Commission of Human Rights has formulated in its two reports, particularly to the General Attorney's Office in the sense of carrying out an exhaustive investigation ${ }^{52}$.

Torture: The CNDH stated that from June 1990 and July 2004, it received 2,166 complaints for cases of torture ${ }^{53}$. In 2006, the same body reported 330 cases; in 2007, 395; in 2008,987 ; in $2010,1,161$ cases were reported, and 1669 cases were filed in $2011^{54}$. In 2013, the CNDH reported 1,078 complaints for cruel, inhuman or degrading treatment ${ }^{55}$. However, it has been considered that these numbers do not correspond with the reality since it is believed that many acts of torture are not denounced to the authorities. Moreover, acts of torture are usually classified as other crimes (e.g. as lesions), so they are not considered in the statistics for torture ${ }^{56}$.

The amount of people affected by the crimes cited above are official numbers provided by the CNDH but if the analysis is moved to the information collected by the NGOs, the data becomes higher. Indeed, the numbers collected by NGOs often can reach double of those indicated by $\mathrm{CNDH}$.

Access to justice is weak, impunity is high, and victims seldom see the perpetrators brought to justice or receive reparations: The Attorney General's Office reported that

58 preliminary investigations were opened for torture between 2008 and 2011, which resulted in 4 indictments. According to the federal judiciary, during the same period, there were 12 prosecutions for torture, resulting in five convictions. The National Statistics Institute (Instituto Nacional de Estadistica y Geografia, INEGI) collects and publishes national data. According to INEGI, between 2006 and 2010, in the federal jurisdiction there was only one prosecution and no convictions for torture. In the same period in the 31 states and the federal district, there were 37 prosecutions

\footnotetext{
${ }^{50}$ See Report by FUNDAR, op. cit. note 12, p.8.

${ }^{51}$ Human Rights Watch, Mexico: Delays, Cover-Up Mar Atrocities Response.

${ }^{52}$ See Inter-American Commission on Human Rights, Situation Report. Special Follow-up Mechanism to the Ayotzinapa Case of the IACHR. See also, e.g. Human Rights Watch, World Report 2018, Mexico (Events of 2017).

${ }^{53}$ Comisión Nacional de Derechos Humanos, "Recomendación general no. 10...”, p. 2.

${ }^{54}$ Amezcua Noriega, Octavio et al (2012), "Reforma al sistema de justicia penal mexicano. Prevención y sanción de la tortura", p. 18. Amnesty International, "Known abusers but victims ignored. Torture and ill-treatment in Mexico", p. 4, [on line], available at http://www.amnesty.org/en/library/asset/ AMR41/063/2012/en/74354a01-4946-4301-b922-8d048782bfeflamr410632012en.pdf.

${ }^{55}$ Comisión Nacional de Derechos Humanos, Informe de Actividades 2013, Tomo I, p. 45, [on line], available at http://www.cndh.org.mx/Informes_Actividades.

${ }^{56}$ Amezcua Noriega, Octavio et al. op. cit. note 54, p. 17.
} 
and 18 torture convictions. However, it is impossible to cross reference this various data sources to obtain an accurate year on year record. ${ }^{57}$

Considering the multiple occurrences of grave human rights violations, highlighted particularly by events carried out with government intervention, the Mexican State has adopted mechanisms to deal with these high-quantity grave human rights violations.

Over the last years, multiple legal and normative measures, early alert mechanisms, public policy initiatives, commissions, agencies, institutional reforms, and coordination strategies have been adopted between 2010 and the date of writing this article in $2018^{58}$, but in light of the staggering reality and the growing numbers and seriousness of the violations involved, they are clearly insufficient and the institutional structure is evidently overcome ${ }^{59}$.

Serious methodological, technological and transparency problems remain in relation to counting the victims, constructing trustworthy databases, coordinating and systematizing the information on victims, patterns of abuse and actors involved within a federal system formed by the federal authorities and 32 federative entities (31 states and Mexico City), and adequately mapping, identifying and diagnosing the extremely complex and multilayered phenomenon of new forms of violence and human rights violations in Mexico ${ }^{60}$. There is a constant reticence by government authorities to openly admit the seriousness of the problems and frequently the public is denied basic information ${ }^{61}$.

The backlog of cases is tremendous, both in the investigative units with legal (and at times overlapping) competence to analyze these issues, as well as at the judicial level, so much so that such bodies choose to renounce the close examination of each case ${ }^{62}$. This

\footnotetext{
${ }^{57}$ Amnesty International, "Known abusers but victims ignored. Torture and ill-treatment in Mexico, see supra note 50 (The footnotes of the original were omitted).

${ }^{58}$ See, e.g. PGR, op. cit. note 12; GARDUÑo, Silvia, "Alistan herramienta para desaparecidos", Reforma Newspaper, 12 October 2014; FUNDAR, Centro de Análisis e Investigación, Movimiento por la Paz con Justicia y Dignidad (MPJD), SERAPAZ, Presentación de información en el marco de la adopción de la lista cuestiones en la Séptima Sesión del Comité Contra las Desapariciones Forzadas 15-26 de septiembre de 2014. Primera revisión a México por el Comité contra las Desapariciones Forzadas de la Organización de las Naciones Unidas, 1 June 2014; Report presented by the Mexican State to the UN Committee on Enforced Disappearances, paras. 228-231.

${ }^{59}$ Human Rights Watch, op. cit note 13.

${ }^{60}$ See, e.g. Aristegui Noticias, op. cit. note 15; FUNDAR, op. cit. note 12; Acuerdo de PGR, [on line], available at, http://dof.gob.mx/nota_detalle.php?codigo=5368881\&fecha=20/11/2014; HuMAN RigHTS Watch, op. cit. note 14 .

${ }^{61}$ For instance, CMDPDH has requested the disclosure of several reports part of the criminal investigation of the massacre of Tlatlaya, but PGR has rejected to comply with this request it arguing this is part of an ongoing investigation, usually a valid basis for rejection, except in the cases of grave human rights violations, as set forth by Mexican law and by the jurisprudence of the Inter-American Court of Human Rights; see Aristegui Noticias, op. cit. note 14. Consider also the lack of public access of the agreement entered into between PGR and the International Committee of the Red Cross for them to provide the software of its database Ante Morten Post Mortem (AMPM) to be implemented by the Mexican authorities as part of the implementation of the UN Convention on Enforced Disappearance, which was not published in the official journal (Diario Oficial de la Federación, DOF) and has been requested by NGOs without success (FUNDAR, MJPD, SERAPAZ, op. cit. note 12, p. 17).

${ }^{62}$ FUNDAR, op. cit. note 12, p. 8; FUNDAR, MJPD, SERAPAZ, op. cit. note 12, p. 17; Acuerdo de PGR, [on line], available at http://dof.gob.mx/nota_detalle.php?codigo $=5368881 \&$ fecha $=20 / 11 / 2014$; HuMAN RighTS WaTCH, op. cit. note 14.
} 
in turn causes the singular less difficult cases to be inextricably mixed-up with the more complex interlinked cases related to drug cartels and organized crime, and at the same time it has raised levels of impunity to astonishing proportions: it is calculated that the probability for a homicide to be denounced and resolved in Mexico City is less than $1 \%$ and this is similar to data in other parts of the country ${ }^{63}$. To this one can add the lack of financial and human resources, as well as poor or inadequate training in many of these institutions, causing a general incompetence, at best, or willful abandonment at worst, among members of these investigative institutions ${ }^{64}$. In parallel, there is a growing call by NGOs for institutions, including the $\mathrm{CNDH}$, to react immediately in cases of grave violations of human rights in a victim-oriented, non-bureaucratic way and to reform the institutional culture more generally towards a strong human rights profile.

\section{Normative framework on grave human rights violations and Crimes Against Humanity}

\section{Constitutional framework}

In 2008 a constitutional reform was carried out resulting in the deepest amendment on criminal law in recent times. The changes include several articles of the Constitution and some other laws, with the purpose of transforming its inquisitorial, written criminal justice system to an adversarial, oral one ${ }^{65}$. But implementation of the reform has been slow and not all of the 32 federative entities have adopted the accusatory system ${ }^{66}$.

At the same time, a human rights reform took place in 2011. The Mexican Constitution was amended in order to expand the protection of human rights ${ }^{67}$. Modifications are very profound and attempt at achieving HR to permeate in all the country: at all levels; in all branches of State activity and in social interaction (i.e., in some cases involving private actors). The amendment changed 11 articles of the Constitution, the most important Article 1: HR contained in international treaties are now constitutional norms within Mexico's legal system. The wording of Article $1^{68}$ of the Mexican Constitution requires authorities to adhere to all international human rights treaties that Mexico has ratified. Therefore, general obligations on HR are fully implemented in the national system, since they are obligations contained in the Constitution.

\footnotetext{
${ }^{63}$ CAmhaj, Elías (2018), "Matar y Morir en Ciudad de México", Periódico El País, 22 September.

${ }^{64}$ Ibid.

${ }^{65}$ On March $5^{\text {th }}, 2014$, the National Code of Criminal Proceedings was issued as the main instrument, after the Constitution, which regulates the amendment of 2008.

${ }^{66}$ National Commission on Security (CNS), [on line], available at http://www.cns.gob.mx/portalWebApp/ wlp.c? $\quad c=1 f b d 5$.

${ }^{67}$ CASSESE, Antonio, Initiative for Justice Peace and Humanity, A new Approach on Human Rights in Mexican Criminal Proceedings, [on line], available at http://www.cassese-initiative.org/global-training/mexico-congress.html.

${ }^{68}$ Constitución Política de los Estados Unidos Mexicanos (Mexican Constitution) 5 February 1917 (as reformed in 2011), Article 1: In the Unites States of Mexico, all persons shall enjoy the rights recognized by the Constitution and international treaties to which the Mexican State is party, as well as guarantees for their protection, the exercise of which may not be restricted or suspended, except in the cases and under the conditions established by this Constitution.
} 
The reform also requires that recommendations of international human rights bodies must be fulfilled in order to bring Mexico in line with international standards, as emphasized by HR bodies ${ }^{69}$.

One of the main normative challenges is the lack of consistency and harmonization between federal and state laws. This is especially blatant in the case of enforced disappearance: for many years the criminal type included in the federal criminal code was different than that foreseen in the criminal codes of the states that had typified enforced disappearance, a fact which led international human rights mechanisms, most notably the UN Working Group on Enforced or Involuntary Disappearances after its 2011 visit to Mexico, to recommend the adoption of a general law on enforced disappearance that would cover all cases nationally under the widest definition possible ${ }^{70}$. This general law was adopted at last in 2017 and entered into force in January $2018^{71}$.

As an umbrella consideration, one must also recall the 2005 Constitutional amendment of Article 21, which sets forth the case by case system in relation to the ICC, whereby the Federal Executive [the President] is empowered to recognize the jurisdiction of the ICC, previous approval of the Senate, in each case.

The Mexican Constitution does not include any mention of CAH as a separate type of domestic or international crimes, nor does the federal legislation, both in criminal or in military matters. This document will concentrate on the analysis of Mexican legislation particularly related to enforced disappearance, torture and extrajudicial killing as $\mathrm{CAH}$ (updated to the date of writing). In this respect, the Mexican Constitution does not define the crimes of enforced disappearance, torture or extrajudicial killing, or refer concretely to the 'chapeau' requirements of the widespread or systematic character of $\mathrm{CAH}$. However, it does prohibit torture as a right of detained or accused persons under its Article 20, B., II. Moreover, as a general principle of the criminal process, it expresses that any evidence obtained through the violation of fundamental rights will be null (Article 20, A., IX).

A mention of enforced disappearance and torture was included within Article 29 of the Constitution referred to the combined Presidential-Federal Congress faculty of restriction or suspension of fundamental rights in cases of national emergency (invasion, grave perturbation of public peace, or any other that places society at grave danger or conflict). The provision was modified through the human rights reform of 10 June 2011 and now sets forth that even in such circumstances of grave risk, the prohibitions of enforced disappearance and of torture are non-derogable and non-suspendable, as well as the judicial guarantees necessary for the protection of such rights.

It also foresees grave violations of human rights in Article 102. Such article was modified via the human rights reform of 2011 to transfer the faculty previously held by the

\footnotetext{
${ }^{69}$ UN Working Group on Enforced or Involuntary Disappearances: the Congress and local legislatures must reconcile federal and state legislation with these constitutional changes, just as the judicial authorities must adapt their jurisprudence to the new constitutional framework, UN Human Rights Council, Report of the Working Group on Enforced or Involuntary, Disappearances. Addendum, 20 December 2011, A/ HRC/19/58/Add.2, 2011, p. 6.

70 See more, [on line], at: http://www.ohchr.org/SP/NewsEvents/Pages/DisplayNews.aspx?NewsI$D=10907 \&$ LangID $=$ S\#sthash.4CbgjuPH.dpuf

${ }^{71}$ Ley General en materia de Desaparición Forzada de Personas, Desaparición Cometida por Particulares y del Sistema Nacional de Búsqueda de Personas, Gaceta Parlamentaria, 12 octubre 2017.
} 
Supreme Court of investigating cases of grave violations of human rights to the CNDH. The CNDH now holds the power of investigating such violations when it is deemed convenient or is requested by the Federal Executive [the President], one of the chambers of the Federal Congress, the Governor of a State, the Head of Government of Mexico City or the legislative bodies of the federative entities ${ }^{72}$. Because of this faculty, in January 2015 the CNDH reclassified its recommendation on the case of the massacre of Tlatlaya, State of Mexico, occurred on 30 June 2014 (Recommendation 51/2014), to consider it as a case of grave violations of human rights, to be taken into account by responsible authorities in the implementation of such recommendation ${ }^{73}$.

On the other hand, on 14 July 2011 (a month after the human rights reform), Article 19 of the Constitution was amended to include a paragraph setting forth that The judge will order preventive imprisonment, proprio motu, in the cases of organized crime, purposeful homicide, rape, kidnapping, human trafficking, crimes committed with violent means such as arms and explosives, and grave crimes defined by law against the security of the nation, the free development of personality and health. Presumably these crimes were specifically included on the basis of the gravity of their commission and in light of the current context of increased violence, a fact which contrasts with the absence of reference to $\mathrm{CAH}$ and of some of the concrete crimes like ED or torture in the list of said grave crimes.

Interestingly in relation to international criminal law, though, the National Code of Criminal Procedures of 2014 adds 'genocide' as one of the crimes deserving proprio motu preventive imprisonment (Article 167). However, one must also consider that this form of preventive imprisonment, as well as the practice of 'arraigo' (long periods of detention of up to 80 days during investigation, constitutionalised by the criminal reform of 2008 and allowed for in case of organized crime), have been critically viewed by international human rights mechanisms ${ }^{74}$. Similar criticisms have been formulated regarding the recently approved Law of Internal Security of 2017 for attempting to legalize, and thus legitimize, intervention of the military in civil policing functions.

As a general provision affecting criminal issues, it must be recalled that the Constitution was reformed on 8 October 2013 to include as a power of Federal Congress that of legislating on the subjects of 'crimes against the federation, organized crime, and to create the single legislation on matters of criminal process' (Article 73, XXI). As a result of such amendment, on 5 March 2014 the National Code of Criminal Procedures was issued. The fact that this is a national law -and not a federal law- contrasts with previous legal tradition and reflects the intention to unify procedural matters in line with the gene-

\footnotetext{
${ }^{72}$ Article 102 , B., paragraph 11 . Under this faculty the CNDH is currently investigating the recent case of the massacre of 22 persons with military intervention in Tlatlaya, State of Mexico, occurred on 30 June 2014.

73 Massacre of 22 persons with military intervention in Tlatlaya, State of Mexico; for the issue of reclassification of the case see, La Jornada (2015), [on line], available at http://www.jornada.unam.mx/ultimas/2015/01/13/cndh-reclasifica-expediente-de-tlatlaya-por-201cviolaciones-graves201d-7251.html, La Jornada, 13 January.

${ }^{74}$ See OHCHR, "First official visit to Mexico by UN Special Rapporteur on Torture Juan E. Méndez", 16 April 2014, [on line], available at http://www.ohchrorg/EN/NewsEvents/Pages/DisplayNews.aspx?New$s I D=14522 \&$ LangID $=E$ See also SNAPP, Zara (2014), Case Matrix Network Blog ICJ Toolkits, 'The need for systematic fact-finding of serious human rights violations in Mexico', 6 November, [on line], available at https://blog.casematrixnetwork.org/toolkits/eventsnews/op-ed-fact-finding-needs-in-mexico/
} 
ral Constitutional reform on criminal law of 2008 that substitutes the inquisitorial for the adversarial oral system of criminal justice.

\section{Federal and 'general' legislation}

Mexico's Federal Criminal Code includes a chapter entitled Delitos Contra la Humani$\mathrm{dad}$, which can be roughly translated as Crimes against Humanity. This chapter comprises two legal provisions: Articles 149 and 149-Bis. Article 149 describes a crime called Violación de los deberes de humanidad, which can be roughly translated as "Violation of the Duties of Humanity." Article 149-Bis describes the crime of genocide ${ }^{75}$. The Federal Criminal Code (FCC) originally of 1931, and last amended on 14 July 2014, included several of the individual actions comprised by $\mathrm{CAH}$ although there is no general legal category of these crimes ${ }^{76}$. Such individual crimes are:

\section{Enforced Disappearance}

Previous legislation on enforced disappearance (former Articles 215-A, B, C and D of the FCC) may be compared to that on similar crimes committed by private parties. Through reforms of June 2014 to the General Law to Prevent and Punish the Crimes on the Subject of Kidnapping (originally of 2010) and to the FCC, penalties for such crimes were severely increased and in some cases duplicated: kidnapping is sanctioned with 40 to 80 years imprisonment, and when the victim is killed by the authors or accomplices of the kidnapping the penalty may rise up to 140 years in prison. Thus, the existence of a general law and harsher penalties reveals the political and legal consideration of these crimes to be more serious when committed by individuals or organized crime, than when the person's disappearance is perpetrated by, or with acquiescence of, State authorities, as in the case of enforced disappearance.

At 2015, there were 23 out of the 32 state legislations (considering the 32 federative entities: 31 states and the entity of Mexico City) that included the crime of enforced disappearance, 3 that had autonomous legislations on the subject and 6 that had no legislation on the matter ${ }^{77}$. Because of this there was a strong impulse especially by civil society for the Federal Congress to adopt a general law on the subject (applicable both at the federal and 32 state levels), to harmonize the criminal type and unify the persecution of the crime nationwide ${ }^{78}$. Some political actors had proposed a legal reform 'to include in the FCC the prohibition to subject torture to statutory limitations and to consider this crime as a $\mathrm{CAH}^{\prime 79}$, although this has not been adopted.

\footnotetext{
${ }^{75}$ See Cámara de Diputados, [on line], available at at http://www.diputados. gob.mx/LeyesBiblio/pdf/9.

${ }^{76}$ For a detailed study, see Villareal Palos, Arturo, 'Los crímenes de genocidio, lesa humanidad y de guerra. Notas para su incorporación a la legislación mexicana', en Anuario Mexicano de Derecho Internacional, vol. XVII, Universidad Nacional Autónoma de México-Instituto de Investigaciones Jurídicas, 2017, pp. 187-218.

${ }^{77}$ Information provided by Eliana García from PGR at the forum on ED held on 19 January 2015, [on line], available at http://www5.diputados.gob.mx/index.php/esl/Comunicacion/Boletines/2015/Enero/19/4958Desaparicion-forzada-de-personas-es-un-crimen-de-Estado. In the case of the states of Guerrero, Chiapas and Querétaro, they derogated the criminal type of ED from their criminal codes and have adopted specific laws on ED.

${ }^{78}$ Human Rights Watch, op. cit. note 13.

${ }^{79}$ See, [on line], available at http://www5.diputados.gob.mx/index.php/esl/Comunicacion/Boletines/2015/
} 
In 2015, the Federal Congress approved a Constitutional reform allowing Congress to issue 'general laws' on enforced disappearances and on torture and give follow-up to process of discussion and approval at the state level, necessary for Constitutional reform to complete approval and enter into force.

As a result of this debate, a new General Law on Enforced Disappearance was approved and entered into force on 16 January 2018. As referred above, the law due to its general legal character, is applicable both to federal authorities and to local authorities at the state and municipal levels in the country's 32 federative entities (31 states and Mexico City). The hope is that with a new normative context, and with the creation of specialized prosecution offices thereof, the implementation of the new law would lead to the development of effective and non-fragmented investigation strategies to bring those responsible to justice and end the prevailing impunity in relation to the disappearance of persons in Mexico. The new law was generally received as a sign of progress by international and national human rights bodies, academics and activists ${ }^{80}$, although some have signaled the lack of implementation and several incidents of non-compliance.

Particularly the UN Working Group on Enforced or Involuntary Disappearances received the news of a general law with satisfaction, as it complied with the recommendation they had issued to Mexico following their visit to the country in 2011.

\section{Torture}

The most important norm to highlight is the new law on the subject, published on 26 June 2017. The current legislative framework consists mainly of the General Law to Prevent, Investigate and Punish Torture and Other Cruel, Inhuman or Degrading Treatment or Punishment, published on 26 June 2017, and thus substitutes the Federal Law to Prevent and Punish Torture, originally of 1991, and reformed in 1994. As in the case of the General Law on Enforced Disappearance, the General Law on Torture law due to its general legal character, is applicable both to federal authorities and to local authorities at the state and municipal levels in the country's 32 federative entities ( 31 states and Mexico City).

On the other hand, the FCC includes the conduct of forcing the accused to declare, using incommunicado detention, intimidation or torture, as part of the crimes of abuse of authority (Article 215, XII; reformed on 30 November 2010), as well as a part of the crimes against the administration of justice (Article 225, XIII; added on 10 January 1994 on the same date as reforms to the Federal Law to Prevent and Punish Torture), in both cases committed by public officials. In the first case, such conduct is punishable with two to nine years imprisonment, 70 to 400 days fine, and disqualification from two to nine years to carry out another public office, employment or commission. In the second case of torture as part of crimes against the administration of justice, there is no penalty mentioned, probably because of referral to the specific law on torture. However, these norms which prevail today are not compatible with the existence of an autonomous crime of torture and the sanctions specifically included thereof in the law on the matter.

Enero/19/4958-Desaparicion-forzada-de-personas-es-un-crimen-de-Estado.

80 See, e.g. UN OHCHR (2018), 'UN experts welcome enforced disappearance law in Mexico', Press release, 16 January, [on line], available at https://www.ohchr.org/en/NewsEvents/Pages/DisplayNews.aspx? NewsID $=22588 \&$ LangID $=E$. 
The previous 1994 Federal Law to Prevent and Punish Torture defined torture in its Article 3 as:

the crime committed by the public servant who, by reason of his or her powers, inflicts on a person pain or suffering, whether physical or mental in order to obtain from the tortured person or a third person, information or a confession, or to punish him or her for an act he has committed or is suspected of having committed, or coerce the person into engaging or not engaging in a particular behavior.

The discomfort or penalties resulting solely from legal sanctions, inherent in or incidental to, or arising from a legitimate act of authority, are not considered torture. In addition to lack of legislation harmonized with international standards, as is well known, in the case of torture one of the main problems that has traditionally existed is implementation: despite the growing number of complaints and criminal demands of this crime, not all criminal files are opened as torture but rather as lesions by the prosecution institutions, and from these, fewer yet are sentenced by a judge as actual commissions of torture ${ }^{81}$. As a result of the human rights Constitutional reform of 2011, in 2012 the Federal Congress discussed amendments to further prohibit -in addition to torture-, cruel, inhuman or degrading treatment of persons subjected to arrest, detention or imprisonment. Such amendments also proposed to incorporate standards of the Istanbul Protocol and to empower the CNDH for visits and supervision, to expose and prevent acts of torture in the prison and social rehabilitation system of the country, as well as within bodies under the Federal Executive responsible for the administration of justice.

Through the reform, the crime would comprise the public servant who inflicts on a person pain or severe physical or mental suffering, for purposes of criminal investigation, as a means of intimidation, as personal punishment, as a preventive measure or for any other purpose. To do this, the proposed reform defined as torture the application of methods upon a person intended to obliterate the personality of the victim or to diminish his or her physical or mental capacity, even without causing physical pain or mental anguish.

Regarding sanctions, the proposed amendments set forth a higher prison sentence than the current one, of seven to sixteen years, 500 to 1000 days fine and permanent disqualification from holding any public office, position or commission. Such penalties would also be applied to public servants who induce a third party or act through such party to inflict a severe pain or suffering, whether physical or mental.

The same penalties would be applied to the third party that for any purpose, instigated, induced or authorized, explicitly or implicitly, by a public official, inflicts severe pain or physical or mental suffering. The proposed amendments further state that under no circumstances that warrant the suspension of the exercise of fundamental rights and guarantees (Article 29 of the Constitution), could the right not to be tortured be suspended ${ }^{82}$, a proposal that was picked up in Article 10 of the 2017 law.

\footnotetext{
${ }^{81}$ See SnAPp, Zara, op. cit. note 74. See also UN Committee Against Torture (CAT), Concluding observations on the combined fifth and sixth periodic reports of Mexico as adopted by the Committee at its forty-ninth session (29 October-23 November 2012), CAT/C/MEX/CO/5-6, 11 December 2012.

82 [on line]. Available at http://diariojuridico.com.mx/actualidad/noticias/reforman-ley-federal-para-prevenir-y-sancionar-la-tortura.html.
} 
Importantly for the effects of crimes against humanity, the legal draft submitted by the Chamber of Deputies (House of Representatives) to the Senate was amended by this last body in April 2013 to increase the penalty up to 24 years in prison for anyone who commits the crime of torture, systematically and as part of a widespread attack against a civilian population. In this last case, the draft declared the crime of torture as not subject to statutory limitations (imprescriptible).

Likewise, the definition of torture was modified and widened in the Senate draft to be considered as an act whose intent is to inflict suffering, intended to obliterate the personality of the victim or to diminish his or her capabilities. The obligation of public servants to report any act of torture was also included in the draft and penalties ranging from fines to disqualification were increased if torture is committed as a systematic act against civilians $^{83}$. This draft approved by the Senate was referred back to the Chamber of Deputies for its discussion, as foreseen by the legislative process. The Chamber approved another draft in November 2014 which then turned back to the Senate for further discussion.

On 26 June 2017 a new Federal Law on the Prevention, Punishment and Eradication of Torture and Other Cruel, Inhuman or Degrading Treatment or Punishment, was published. These changes take effect in relation to the previous Federal Law to Prevent and Punish Torture (1994). The current law of 2017 sets forth in Article 24 that

The crime of torture is committed by the public servant who, in order to obtain information or a confession, for purposes of criminal investigation, as a means of intimidation, as a personal punishment, as a means of coercion, as a preventive measure, or for reasons based on discrimination, or with any other purpose:

\section{Causes pain or physical or mental suffering to a person;}

II. Carries out behavior that is directed or capable of diminishing or nullifying the personality of the victim or his or her physical or psychological ability, even if it does not cause pain or suffering, or

III. Performs medical or scientific procedures on a person without their consent or without the consent of who could legally grant it.

Article 25 of the same law also specifies that the crime of torture consistent in the actions described by Article 24 may also be committed by any individual with the authorization, support or acquiescence of a public servant; or with any degree of authorship or participation.

At the same time, the new law of 2017 states in Article 8 that 'The exercise of criminal action and the sanction imposed judicially for the crime of torture is not susceptible to statutory limitations' ('imprescriptible'), a norm which goes in line with Mexico's obligations under the UN Convention on the Non-Applicability of Statutory Limitations to War Crimes and Crimes against Humanity, and with previous jurisprudence of the Mexican Supreme Court to this same effect. However, while the law refers in passing to grave human rights violations (Article 91, V. a.), it did not pick up the proposal of regulating cases of systematic attacks on the civilian population, an aspect which would have moved it closer to the integral international definition of crimes against humanity.

\footnotetext{
83 "Aprueba Senado sanción de hasta 24 años de cárcel por tortura", in La Razón, 24 April 2013, [on line], available at $h t t p: / /$ razon.com.mx/spip.php? article169590
} 


\section{Extrajudicial killing}

Despite the gravity of such occurrences in Mexico, particularly by the hands of the military -controversially in charge since 2006 of certain public security tasks (constitutionally reserved to civilian authorities)- ${ }^{84}$, there is no federal or general law on the subject. The Federal Criminal Code (FCC) and the 32 state criminal codes only include specific criminal types of homicide or qualified homicide.

To provide a general outlook, let us review the Federal Criminal Code (FCC), whose norms are like the state criminal codes on this topic, and therefore the analysis may be extrapolated to reach general conclusions. The FCC foresees the crime of homicide, and it includes general provisions of aggravated penalties in the case of crimes committed by public officials, it does not set forth any specific additional penalty in the case of homicide, while it does so in relation to other crimes (robbery, unjustified enrichment, or rape, for instance). There is no aggravation via 'qualified homicide' when committed against public officials either, as there is in the case of the Criminal Code of Baja California, for instance, which increases penalization for homicide when performed against members of police institutions or private security providers, as reviewed below.

Interestingly, there are aggravated penalties in the case specifically of crimes against journalists when committed by public officials, according to the last two paragraphs of Article 51 of the FCC, added on 3 May 2013 presumably due to the context of increased violence against this group:

When a purposeful criminal offense committed against a journalist, person or facility with the intention to affect, limit or impair the right to information and freedom of expression or printing, the penalty for such an offense shall be increased by one third.

In the former case, the penalty is increased by one half when the offense is committed in addition by a public servant in the performance of his or her duties or the victim is female and the crime was committed on the basis of gender, as established by the laws in the matter.

\section{Some reflections on legal application and interpretation issues}

The Constitutional supremacy of international human rights instruments: regardless of any federal or state law incorporating implementation standards for crimes against humanity, on the basis of Article 133 (legal hierarchy of international instruments) and reformed Article 1 (constitutional supremacy of human rights norms) of the Constitution, international human rights treaties (where the ICC Statute could be included) are directly applicable to grave human rights violations/CAH and mandatory for all authorities, branches and levels of government of the Mexican State. Because of this trend, currently there are discussions taking place at the level of federal legislative power to consider enforced disappearance and torture as $\mathrm{CAH}$ in the case of widespread and systematic attacks against civilian population, in line with ICC standards.

\footnotetext{
${ }_{84}$ See Guevara, José Antonio (2014), 'Ejecuciones extrajudiciales en México', 29 September, [on line], available at http://www.animalpolitico.com/blogueros-verdad-justicia-reparacion/2014/09/29/las-ejecuciones-extrajudiciales-en-mexico/.
} 
The human rights reform of 2011: the Mexican Constitution was amended on 10 June 2011 in order to expand the protection of human rights ${ }^{85}$. Modifications are very profound and attempt at achieving human rights to permeate in all the country: at all levels; in all branches of State activity and in social interaction (i.e., in some cases involving private actors). The amendment changed 11 articles of the Constitution, the most important Article 1: human rights contained in international treaties are now constitutional norms within Mexico's legal system. The wording of Article $1^{86}$ of the Mexican Constitution requires authorities to adhere to all international human rights treaties that Mexico has ratified. Therefore, general obligations on human rights are fully implemented in the national system, since they are obligations contained in the Constitution. The reform also requires that recommendations of international human rights bodies must be fulfilled in order to bring Mexico in line with international standards, as emphasized by HR bodies ${ }^{87}$.

Criminal Reform of 2008: this is the deepest amendment on criminal law in recent times and thus should also be considered. The changes include several articles of the Constitution and some other laws, with the purpose of transforming its inquisitorial, written criminal justice system to an adversarial, oral one ('sistema acusatorio'). The new proceedings are being implemented in the country ${ }^{88}$. But, as recalled above, implementation of the reform has been slow. Some specific effects as related to international criminal law and CAH are derived from this reform, as explained in the Constitutional framework and each of the analyzed crimes above.

Mexico and the UN Convention on the Non-Applicability of Statutory Limitations to War Crimes and Crimes against Humanity: apart from the fact that Mexico is a party to the ICC Statute since 2006 and to the main international instruments on enforced disappearan and torture, it must also be recalled that it is a party to the 1968 UN Convention on the Non-Applicability of Statutory Limitations to War Crimes and Crimes against Humanity, since 15 March 2002. Upon ratification of the Convention, Mexico presented an interpretative declaration stating that based on Article 14 of its Constitution (non-retroactivity), only crimes committed after the entry into force of the Convention for Mexico (13 June 2002) would be considered subject to this instrument. In this respect, the crimes committed from Calderon's presidency (2006-2012) onwards would undoubtedly enter into the sphere of application of the convention, and the fact that Mexico is a (latecomer) party to

\footnotetext{
${ }^{85}$ Antonio Cassese Initiative for Justice Peace and Humanity, A New Approach on Human Rights in Mexican Criminal Proceedings, [on line], available at http://www.cassese-initiative.org/global-training/mexico-congress.html.

${ }^{86}$ Constitución Política de los Estados Unidos Mexicanos (Mexican Constitution) 5 February 1917 (as reformed in 2011), Article 1: In the Unites States of Mexico, all persons shall enjoy the rights recognized by the Constitution and international treaties to which the Mexican State is party, as well as guarantees for their protection, the exercise of which may not be restricted or suspended, except in the cases and under the conditions established by this Constitution.

${ }^{87}$ UN (2011) Working Group on Enforced or Involuntary Disappearances: the Congress and local legislatures must reconcile federal and state legislation with these constitutional changes, just as the judicial authorities must adapt their jurisprudence to the new constitutional framework, UN Human Rights Council, Report of the Working Group on Enforced or Involuntary, Disappearances. Addendum, 20 December 2011, A/HRC/19/58/Add.2, 2011, p. 6.

${ }^{88}$ On 5 March 2014, the National Code of Criminal Proceedings was issued as the main instrument, after the Constitution, which regulates the amendment of 2008
} 
it reflects the current political consideration that $\mathrm{CAH}$ are part of the most serious crimes recognized by the Mexican legal system.

At the same time, the consideration that led to the ratification of the convention and other human rights international instruments, contrasts with other political assumptions reflected in recent Constitutional and legal amendments, for example, the Constitutional inclusion in 2011 of certain crimes contemplated as 'grave' and lacking the mention within that catalogue of enforced disappearance, torture and extrajudicial killing (Article 19 as explained above). It contrasts as well with the total lack of mention of CAH in any Constitutional or legal provision as of today.

\section{Conclusions}

Grave or serious human rights violations and $\mathrm{CAH}$ are closely related in international law and practice. Cases such as that of Mexico engaged in a drug war -and not a formal armed conflict- and affected by tens of thousands of grave violations including by criminal organizations, are difficult to categorize. Social actors and national and local human rights institutions have contributed significantly to documenting cases and constructing creative avenues for action. At the same time, the current international scenario poses a challenging moment, during the drafting of an autonomous treaty on crimes against humanity.

In Mexico there is a general reticence to legislate fully on CAH, probably because of the generalized denial or minimization by public officials of the real magnitude of the problem. At present, though, the voice of victims' families, the power of such high-quantity incidents and existing data, in addition to the momentum in place with a newly elected President and incipient government, and the debate on innovative international standards, open the door to the possibility of change.

More effective and precise tools and methodologies are essential for documenting the grave human rights violations and crimes suffered by people in Mexico, particularly those in conditions of vulnerability or more exposed to risk, such as women and girls, migrants, and persons living in poverty and social marginalization.

This will help make visible their specific needs and the structural impediments to attend them, as well as providing objective criteria to orient decision-making towards policies and norms that at last may start guaranteeing truth, justice and reparation for victims.

\section{Bibliography}

Amezcua Noriega, Octavio, et al. "Reforma al sistema de justicia penal mexicano. Prevención y sanción de la tortura".

Amnesty International “Informe Anual 2013-Mexico”, Mexico.

,"Known abusers but victims ignored. Torture and ill-treatment in Mexico", 2012, [on line], available at http://www.amnesty.org/en/library/asset/AMR41/063/2012/ en/74354a01-4946-4301-b922-8d048782bfef/amr410632012en.pdf

(2009), "México, Nuevos Informes de Violaciones de Derechos Humanos a Manos del Ejército". 
CASSESE, Antonio (2005), International Law, $2^{\text {nd }}$ ed, Oxford, Oxford University Press.

, Initiative for Justice Peace and Humanity, A new Approach on Human Rights in Mexican Criminal Proceedings, [on line], available at http://www.cassese-initiative.org/global-training/mexico-congress.html

Aristegui Noticias (2014), "La PGR no quiere transparentar su investigación sobre la matanza de Tlatlaya", 11 December, [on line], available at http://aristeguinoticias. com/0812/mexico/la-pgr-no-quiere-transparentar-su-investigacion-sobre-la-matanza-de-tlatlaya/

Camhaj, Elías (2018), "Matar y Morir en Ciudad de México", Periódico El País, 22 September.

Cançado Trindade, Antonio Augusto (2006), A humanizaçao do direito internacional, Editora del Rey, Brasil.

(2010), International Law for Humankind: Towards a New Jus Gentium, Martinus Nijhoff Publishers, The Netherlands, July.

Case Matrix Network Blog ICJ Toolkits, "The need for systematic fact-finding of serious human rights violations in Mexico", by Zara Snapp, 6 November 2014, [on line], available at https://blog.casematrixnetwork.org/toolkits/eventsnews/op-ed-factfinding-needs-in-mexico/

Castilla JuÁrez, Karlos (2018), “Asesinato de personas migrantes sine permissum en tránsito ¿un crimen de lesa humanidad competencia de la Corte Penal Internacional?", in Revista Mexicana de Ciencias Penales, No. 4, abril-junio.

Comisión Nacional de Derechos Humanos (2015), reclasifica expediente de Tlatlaya por 201 violaciones graves, [on line], available at http://www.jornada.unam. $\mathrm{mx} /$ ultimas/2015/01/13/cndh-reclasifica-expediente-de-tlatlaya-por-201cviolaciones-graves201d-7251.html, La Jornada, 13 January.

(2013), Comisión Nacional de los Derechos Humanos, Informe de Actividades 2013, Tomo I.

(2013), Agenda Nacional de Derechos Humanos 2013.

(2013), Recomendación No. 80/2013 Caso de Privación de la vida de 72 personas migrantes y atentados a la vida de los extranjeros, en el Municipio de San Fernando, Tamaulipas, Mexico.

Comité de Migrantes Fallecidos y Desaparecidos de El Salvador et al., Informe, Situación de las personas migrantes no localizadas y restos no identificados en México, [on line], available at http://www.fundacionjusticia.org/wp-content/uploads/2013/06/ANEXO-17-INFORME-CIDH-Migrantes-no-localizados-y-restos-no-identificados-en-Mexico.pdf

Constitución Política de los Estados Unidos Mexicanos (Mexican Constitution). 
Crimes Against Humanity Initiative, [on line], available at http://law.wustl.edu/WashULaw/crimesagainsthumanity/

Dondé Matute, Javier (2018), "Una propuesta de justicia transicional para México", in Animal Político, 26 September.

General Law on the Prevention, Punishment and Eradication of Torture and Other Cruel, Inhuman or Degrading Treatment or Punishment, Diario Oficial de la Federación, 26 June 2017.

FidH (International Federation on Human Rights, 2017), "Mexico: Murders, Disappearances, and Torture in Coahuila de Zaragoza are Crimes against Humanity", 5 July, [on line], available at https://www.fidh.org/en/region/americas/mexico/mexico-murders-disappearances-and-torture-in-coahuila-de-zaragoza-are

(2018), "Military and civil authorities reported to the International Criminal Court for crimes against humanity committed in Chihuahua, Mexico", 11 June, [on line] available at https://www.fidh.org/en/region/americas/mexico/military-and-civil-authorities-reported-to-the-international-criminal.

FUNDAR (2014), Centro de Análisis e Investigación, Movimiento por la Paz con Justicia y Dignidad (MPJD), SERAPAZ, Presentación de información en el marco de la adopción de la lista cuestiones en la Séptima Sesión del Comité Contra las Desapariciones Forzadas 15-26 de septiembre de 2014. Primera revisión a México por el Comité contra las Desapariciones Forzadas de la Organización de las Naciones Unidas, 1 June 2014.

GARDUÑo, Silvia (2014), “Alistan herramienta para desaparecidos”, Reforma Newspaper, 12 October.

General Gallardo (2018), "Ley de Seguridad Interior y la Corte Penal Internacional", Sin Embargo, 17 January, [on line], available at http://www.sinembargo.mx/17-01$2018 / 3374562$

General Law on Enforced Disappearance (Ley General en materia de Desaparición Forzada de Personas, Desaparición Cometida por Particulares y del Sistema Nacional de Búsqueda de Personas), entered into force in January 2018.

Geneva Academy of International Humanitarian Law and Human Rights (2014), What amounts to 'a serious violation of international human rights law'? An analysis of practice and expert opinion for the purpose of the 2013 Arms Trade Treaty, Geneva Academy, Academic Briefing No. 6, August.

Gómez Romero, Luis (2018), "Massacres, disappearances and 1968: Mexicans remember the victims of a "perfect dictatorship", The Conversation, 5 October, [on line], available at https://theconversation.com/massacres-disappearances-and-1968mexicans-remember-the-victims-of-a-perfect-dictatorship-104196

Goransky, Mirna and Luis Piqué, María (2010) “(The Lack of) Criteria for the Selection of Crimes Against Humanity Cases: The Case Of Argentina", in Morten Bergsmo, 
Criteria for Prioritizing and Selecting Core International Crimes Cases, $2^{\text {nd }}$ ed, Torkel Opsahl Academic EPublisher, Oslo.

Guevara, José Antonio (2014), "Ejecuciones extrajudiciales en México", 29 September, [on line], available at http://www.animalpolitico.com/blogueros-verdad-justicia-reparacion/2014/09/29/las-ejecuciones-extrajudiciales-en-mexico/

Human Rights Watch (2014), Mexico: 'Disappearances' Response Falls Short: Inexplicable Delays, Contradictory Statements, Limited Results, 8 October 2014, [on line], available at http://www.hrw.org/news/2014/10/08/mexico-disappearances-response-falls-short

(2013), Mexico: Build Accurate Database of Disappeared, 12 November, [on line], available at http://www.hrw.org/news/2013/11/12/mexico-build-accurate-database-disappeared.

(2013), Mexico's Disappeared: The Enduring Cost of a Crisis Ignored, February, [on line], available at http://www.hrw.org/reports/2013/02/20/mexicos-disappeared.

, World Report 2014-Mexico, [on line], available at http://www.hrw.org/world-report/2014/country-chapters/mexico.

, World Report 2018-Mexico, [on line], available at https://www.hrw.org/es/ world-report/2018/country-chapters/313310.

Inter-American Commission on Human Rights (2018), Situation Report. Special Follow-up Mechanism to the Ayotzinapa Case of the IACHR, OEA/Ser.L/V/II, Doc. 82,5 June.

Lastri, Diana (2018), "Dos jueces consideran inconstitucional la Ley de Seguridad Interior", El Universal, 11 May, [on line], available at http://www.eluniversal.com.mx/ nacion/dos-jueces-consideran-inconstitucional-la-ley-de-seguridad-interior

Medina Quiroga, Cecilia (1988), The Battle of Human Rights, Gross, Systematic Violations and the Inter-American System, Martinus Nijhoff, Dordrecht, The Netherlands.

Mexican Government, Report presented by the Mexican State to the UN Committee on Enforced Disappearances.

Open Society Justice (20176), Initiative, Atrocidades Innegables: Confrontando Crímenes de Lesa Humanidad en México.

Pérez-León Acevedo, Juan Pablo (2017), “The Close Relationship Between Serious Human Rights Violations and Crimes Against Humanity: International Criminalization of Serious Abuses", in Anuario Mexicano de Derecho Internacional, 147, vol. XVII

Procuraduría General de la República (2013, Acuerdo A/066/13 por el que se crea la Unidad Especializada de Búsqueda de Personas Desaparecidas y se establecen sus facultades, Diario Oficial de la Federación, 21 June. 
Robinson, Darryl (2015), "Mexico: The War on Drugs and the Boundaries of Crimes Against Humanity", in EJIL: Talk!, 26 May, [on line], available at https://www.ejiltalk.org/mexico-the-war-on-drugs-and-the-boundaries-of-crimes-against-humanity/

Sunga, Lyal S. (2009), "The Concept of Human Security: Does it Add Anything of Value to International Legal Theory or Practice?" in Frick, Marie-Luisa and Oberprantacher, Andreas (editors), Power and Justice in International Relations. Interdisciplinary Approaches to Global Challenges, Ashgate Publishers, December.

Teitel, Ruti G. (2011), Humanity's Law, Oxford University Press.

UN Human Rights Council (2011), Report of the Working Group on Enforced or Involuntary, Disappearances Addendum, Mission to Mexico, 20 December 2011, A/ HRC/19/58/Add.2.

UN OHCHR (2014), 'First official visit to Mexico by UN Special Rapporteur on Torture Juan E. Méndez', 16 April, [on line], available at http://www.ohchr.org/EN/NewsEvents/Pages/DisplayNews.aspx?NewsID=14522\&LangID $=\mathrm{E}$

(2018), "UN experts welcome enforced disappearance law in Mexico", Press release, 16 January, [on line] available at https://www.ohchr.org/en/NewsEvents/ Pages/DisplayNews.aspx?NewsID $=22588 \&$ LangID $=\mathrm{E}$

UN Secretary-General (2004), Report to the Security Council on the protection of civilians in armed conflict, UN doc. S/2004/431, 28 May.

UN (2011), Human Rights Due Diligence Policy on UN support to non-UN security forces (HRDDP).

Villareal Palos, Arturo (2017), "Los crímenes de genocidio, lesa humanidad y de guerra. Notas para su incorporación a la legislación mexicana", en Anuario Mexicano de Derecho Internacional, vol. XVII, Universidad Nacional Autónoma de MéxicoInstituto de Investigaciones Jurídicas. 